\title{
Short communication: Effect of dietary phosphorus deprivation in late gestation and early lactation on the calcium homeostasis of periparturient dairy cows
}

\author{
I. Cohrs, ${ }^{*}$ M. R. Wilkens, $\nmid$ and W. Grünberg ${ }^{*} \ddagger^{1}$ \\ ${ }^{*}$ Clinic for Cattle, and \\ †Institute of Physiology, University of Veterinary Medicine Hannover, Foundation, Hanover, 30173 Germany \\ fDepartment of Farm Animal Health, Utrecht University, Utrecht, $3584 \mathrm{CL}$ the Netherlands
}

\begin{abstract}
Environmental concerns with $\mathrm{P}$ of animal origin polluting surface waters are leading to legal incentives aimed at reducing the dietary $\mathrm{P}$ content of dairy cow rations to the lowest possible level that does not negatively affect health and productivity. The objective of the present study was to determine the effect of feeding rations with low dietary $\mathrm{P}$ content in late gestation on the Ca homeostasis of the periparturient dairy cow. Eighteen multiparous dairy cows were either fed a Pdeficient $(0.15 \% \mathrm{P}$ in dry matter antepartum and $0.20 \%$ $\mathrm{P}$ in dry matter postpartum) but otherwise balanced ration or a control ration with adequate $\mathrm{P}$ content $(0.28 \%$ $\mathrm{P}$ in dry matter antepartum and $0.44 \% \mathrm{P}$ in dry matter postpartum) during the last 4 wk of gestation until d 10 postpartum. Blood was obtained before initiation of P-deprivation (baseline) and $-10,-2,+1,+3$, and $+10 \mathrm{~d}$ relative to parturition to be analyzed for plasma concentrations of $\mathrm{Ca}[\mathrm{Ca}]$ and inorganic phosphate [Pi]. In addition, plasma concentrations of parathyroid hormone $[\mathrm{PTH}]$, the bone resorption marker CrossLaps [CTX], 25-hydroxyvitamin D, and 1,25-dihydroxyvitamin D were determined in a subset of samples. Feeding a P-deficient diet for $4 \mathrm{wk}$ antepartum positively affected the Ca homeostasis of periparturient cows. Clinical hypocalcemia occurred in 3/9 control and 0/9 P-deprived cows. [Calcium], [PTH], and plasma concentrations of vitamin D metabolites did not differ between groups until parturition, whereas [Pi] was decreased and [CTX] significantly increased in P-deprived animals. At parturition $[\mathrm{PTH}]$ was significantly greater in control cows compared with P-depleted cows. The P-deprived cows had significantly higher $[\mathrm{Ca}]$ than control cows on $\mathrm{d}$ $+1(2.46 \pm 0.11$ vs. $2.27 \pm 0.41 \mathrm{mmol} / \mathrm{L})$ and $+2(2.61$ \pm 0.13 vs. $2.35 \pm 0.25 \mathrm{mmol} / \mathrm{L})$. Plasma $[\mathrm{CTX}]$ was
\end{abstract}

Received February 24, 2018.

Accepted June 19, 2018.

${ }^{1}$ Corresponding author: waltergruenberg@yahoo.com significantly higher in P-deprived than in control cows on $\mathrm{d}+2$. Bone resorption and the typical increase in 1,25-dihydroxyvitamin $\mathrm{D}$ in periparturient $\mathrm{P}$-deprived cows seemed to occur despite the smaller rise of [PTH], suggesting either greatly increased sensitivity to PTH or bone mobilization independent of PTH. Future studies must explore potentially negative effects of Pdeprivation antepartum on health and productivity of the dairy cow in the following lactation.

Key words: hypocalcemia, parathyroid hormone, vitamin D, CrossLaps, bone mobilization

\section{Short Communication}

Periparturient hypocalcemia remains one of the economically most important metabolic disorders of dairy cows (Reinhardt et al., 2011; Oetzel, 2013). While periparturient hypocalcemia of cattle was almost exclusively associated with recumbency around calving in the past, numerous recent studies have elucidated the role of subclinically decreased plasma $\mathrm{Ca}$ concentrations ([Ca]) during the periparturient period on health and well-being of high producing dairy cows (Curtis et al., 1983; Martinez et al., 2014; Rodriguez et al., 2017). Acknowledgment of the importance of the plasma [Ca] around calving led to a shift of the focus toward monitoring the plasma [Ca] rather than the incidence of clinical hypocalcemia when assessing the efficacy of a strategy for prevention of hypocalcemia. At the same time the relevance of the plasma inorganic phosphate concentrations $([\mathbf{P i}])$ in periparturient cows remains controversial. Although restricted dietary P supply to dairy cows in late gestation and around calving is perceived as a potential risk for health and productivity by many veterinarians, nutritionists, and producers in the field (Grünberg, 2014), legal incentives targeting at reducing the dietary $\mathrm{P}$ content of cattle rations to the lowest possible level that does not negatively affect health and productivity are implemented in many parts of the world (Goff, 2018). 
The negative effect of excessive dietary $\mathrm{P}$ in late gestation on the plasma [Ca] of the periparturient dairy cow is well established (Peterson et al., 2005; Lean et al., 2006). Limited information is available, however, on the effect of transient but marked dietary $\mathrm{P}$ deprivation in late gestation on the calcium balance of the dairy cow around calving. Reducing dietary $\mathrm{P}$ from 0.44 to $0.21 \%$ prepartum, corresponding to the lower end of current recommendations for dietary $\mathrm{P}$ supply for dry cows, resulted in a less pronounced decrease in plasma [Ca] at parturition but did not alter the concentration of biomarkers for bone metabolism, the plasma concentrations of parathyroid hormone (PTH), or the active form of vitamin D in dairy cows (Peterson et al., 2005). As regulatory mechanisms affecting intestinal absorption, renal secretion, and mobilization of $\mathrm{Ca}$ and $\mathrm{Pi}$ from bone interact in many ways (Bergwitz and Jüppner, 2010), the objective of the present study was to determine how a marked reduction of the dietary $\mathrm{P}$ supply in late gestation affects the Ca balance of dairy cows during the periparturient period. We hypothesized that dietary $\mathrm{P}$ deprivation in the weeks before calving would result in enhanced bone mobilization before calving and would thereby alleviate the decline of plasma [Ca] commonly observed in periparturient dairy cows.

The national and institutional guidelines for the care and use of experimental animals were followed and all experimental procedures were approved by Utrecht University Institutional Animal Care and Use Committee (permit no AVD108002016616). This study is part of a multi-institutional project evaluating the effect of dietary $\mathrm{P}$ deprivation in dairy cows during various stages of the production cycle. To further understand the molecular mechanisms through which $\mathrm{P}$ depletion may affect various organ systems of the dairy cow at different stages of the lactation cycle, other laboratories are currently conducting studies on liver and muscle tissue as well as on leukocytes obtained from these transition cows. The present study focuses on the effect of dietary $\mathrm{P}$ deprivation on Ca homeostasis in the periparturient period.

A total of 18 multiparous dairy cows determined to be healthy based on physical and hematological examination were included in this study. Animals were housed in tiestalls with rubber bedding covered with sawdust in a temperature-controlled environment. Cows were at least 2 wk dry and 6 wk before expected calving at the time of inclusion. The study consisted of a 2 -wk acclimation period that was followed by a period of dietary $\mathrm{P}$ deprivation extending from 4 wk before the expected calving date to $10 \mathrm{~d}$ p.p. Cows were paired by lactation number and previous $305 \mathrm{~d}$ milk yield and one cow of each pair was assigned to one of the 2 experi- mental groups by random allocation. The experimental groups were the low $\mathrm{P}(\mathbf{L P})$ group and the control $(\mathbf{C O N})$ group. Cows in the LP group were offered a P-deficient but otherwise balanced dry cow TMR from $4 \mathrm{wk}$ before expected calving to the day of calving and were thereafter switched to a P-deficient but otherwise balanced TMR for lactating cows. Cows of the CON group were fed the identical dry cow or lactating cow TMR, depending on the stage of lactation, which was supplemented with $\mathrm{NaH}_{2} \mathrm{PO}_{4}$ to obtain an adequate dietary P content (NRC, 2001). During the acclimation period that immediately preceded dietary $\mathrm{P}$ deprivation, both groups were offered the dry cow TMR of the CON group. The experimental rations were based on corn silage, beet pulp, and grass seed straw. Ration details are presented in Table 1 . The $\mathrm{P}$ contents of the rations of groups LP and CON were 0.15 and $0.28 \%$ in $\mathrm{DM}$ in the dry cow ration and 0.20 and $0.44 \%$ in DM in the lactating cow ration, respectively. The dietary $\mathrm{P}$ concentration in rations of the LP group was the lowest content we were able to obtain using standard ingredients in an otherwise balanced ration and was less than $60 \%$ of the NRC (2001) recommended dietary P levels before and after calving. Cows were fed twice daily at standardized times. During the dry period feed intake was restricted to $12.5 \mathrm{~kg}$ of $\mathrm{DM} / \mathrm{d}$, and after calving cows were fed ad libitum.

Attitude and behavior of the cows were monitored daily and a thorough physical exam was conducted once a week. During the calving period, study animals were under constant veterinary supervision to ensure a smooth calving process and early recognition of periparturient hypocalcemia such as coolness to the touch, dullness, muscle weakness, or mild rumen bloat. If early signs of hypocalemia were apparent, blood biochemical analysis was initiated to confirm the diagnosis. Oral or parenteral treatment with $\mathrm{Ca}$ salts was initiated as deemed necessary by the attending veterinarian.

Blood samples were obtained by puncture of the jugular vein 3 times a week between 0700 and $0800 \mathrm{~h}$. Additional blood samples were obtained the day after calving at the same time if this was not a regular sampling day. To follow the development of the parameters investigated in this study over time relative to calving, sampling times were expressed as day relative to calving. Because blood was not collected daily and thus samples were not obtained on the same day relative to calving time clusters were assigned to each designated sampling time. Baseline values were determined in samples obtained at the end of the acclimation period. Sampling time $\mathrm{d}-10$ relative to calving $(\mathrm{d}-10)$ included one sample per cow obtained on d 11, 10, or 9 antepartum (a.p.). Sampling time $-2(\mathrm{~d}-2)$ included 
Table 1. Ingredients and composition of experimental rations of low $\mathrm{P}(\mathrm{LP})$ and control (CON) groups during the dry period (antepartum) and early lactation (postpartum) ${ }^{1}$

\begin{tabular}{|c|c|c|c|c|}
\hline Item & $\begin{array}{c}\text { Control } \\
\text { antepartum }\end{array}$ & $\begin{array}{c}\mathrm{LP} \\
\text { antepartum }\end{array}$ & $\begin{array}{c}\text { Control } \\
\text { postpartum }\end{array}$ & $\begin{array}{c}\text { LP } \\
\text { postpartum }\end{array}$ \\
\hline \multicolumn{5}{|l|}{ Ingredient ( $\%$ of DM) } \\
\hline Corn silage & 29.2 & 29.4 & 39.1 & 39.6 \\
\hline Grass seed straw $^{2}$ & 25.8 & 26.0 & 12.4 & 12.6 \\
\hline Beet pulp & 35.2 & 35.5 & 36.1 & 36.6 \\
\hline Soybean meal & 0 & 0 & 8.7 & 8.8 \\
\hline Palatinose $^{3}$ & 4.8 & 4.8 & 0 & 0 \\
\hline Urea & 0.68 & 0.68 & 0.34 & 0.35 \\
\hline Coated urea & 2.03 & 2.05 & 1.00 & 1.01 \\
\hline Mineral mix & $1.56^{4}$ & $1.57^{4}$ & $1.10^{5}$ & $1.11^{5}$ \\
\hline $\mathrm{NaH}_{2} \mathrm{PO}_{4}$ & 0.67 & 0 & 1.23 & 0 \\
\hline \multicolumn{5}{|l|}{ Chemical analysis } \\
\hline $\mathrm{DM}(\%$ as fed $)$ & 60.0 & 59.3 & 58.3 & 58.2 \\
\hline $\mathrm{NE}_{\mathrm{L}}(\mathrm{MJ} / \mathrm{kg}$ of $\mathrm{DM})$ & 5.90 & 5.88 & 6.48 & 6.54 \\
\hline $\mathrm{DVE}^{6}(\mathrm{~g} / \mathrm{kg}$ of $\mathrm{DM})$ & 61.0 & 60.7 & 79.4 & 80.4 \\
\hline $\mathrm{OEB}^{7}(\mathrm{~g} / \mathrm{d})$ & 18.1 & 17.9 & 11.8 & 12.0 \\
\hline Starch $(\mathrm{g} / \mathrm{kg}$ of $\mathrm{DM})$ & 111 & 110 & 153 & 154 \\
\hline $\mathrm{Ca}(\mathrm{g} / \mathrm{kg}$ of $\mathrm{DM})$ & 4.35 & 4.38 & 5.8 & 5.7 \\
\hline $\mathrm{K}(\mathrm{g} / \mathrm{kg}$ of $\mathrm{DM})$ & 13.5 & 13.4 & 14.1 & 14.5 \\
\hline $\mathrm{P}(\mathrm{g} / \mathrm{kg}$ of $\mathrm{DM})$ & 2.83 & 1.52 & 4.41 & 2.03 \\
\hline $\mathrm{Mg}(\mathrm{g} / \mathrm{kg}$ of $\mathrm{DM})$ & 3.47 & 3.51 & 1.83 & 1.8 \\
\hline $\mathrm{S}(\mathrm{g} / \mathrm{kg}$ of $\mathrm{DM})$ & 1.24 & 1.25 & 1.36 & 1,41 \\
\hline $\mathrm{Na}(\mathrm{g} / \mathrm{kg}$ of $\mathrm{DM})$ & 4.3 & 1.82 & 3.62 & 1.5 \\
\hline DCAD $(\mathrm{mEq} / \mathrm{kg}$ of $\mathrm{DM})$ & 109.9 & 105.0 & 294.6 & 290.8 \\
\hline
\end{tabular}

${ }^{1}$ Cows of the LP group received the antepartum ration of the CON group during the acclimation period.

${ }^{2}$ Grass seed straw from smooth meadow-grass (Poa pratensis) known for its quality and palatability, which is similar to common grass hay.

${ }^{3}$ Palatinose was used as substitute for molasses to stimulate rumen fermentation, but without increasing the dietary K content.

${ }^{4}$ Mineral mix containing Ca $(0 \mathrm{~g} / \mathrm{kg}), \mathrm{Mg}(180 \mathrm{~g} / \mathrm{kg}), \mathrm{Na}(100 \mathrm{~g} / \mathrm{kg}), \mathrm{Cu}(1.655 \mathrm{~g} / \mathrm{kg})$, Co $(0.022 \mathrm{~g} / \mathrm{kg}), \mathrm{Mn}$ $(0.9 \mathrm{~g} / \mathrm{kg}), \mathrm{Zn}(0.65 \mathrm{~g} / \mathrm{kg}), \mathrm{I}(0.01 \mathrm{~g} / \mathrm{kg})$, Se $(0.015 \mathrm{~g} / \mathrm{kg})$, vitamin A $(340,000 \mathrm{IU} / \mathrm{kg}), \beta$-carotene $(0.6 \mathrm{~g} / \mathrm{kg})$, vitamin $\mathrm{D}_{3}(140,000 \mathrm{IU} / \mathrm{kg})$, and vitamin $\mathrm{E}(8,000 \mathrm{IU} / \mathrm{kg})$.

${ }^{5}$ Mineral mix containing Ca $(170 \mathrm{~g} / \mathrm{kg}), \mathrm{Mg}(38 \mathrm{~g} / \mathrm{kg})$, Na $(120 \mathrm{~g} / \mathrm{kg}), \mathrm{Cu}(0.73 \mathrm{~g} / \mathrm{kg})$, Co $(0.009 \mathrm{~g} / \mathrm{kg}), \mathrm{Mn}$ $(1.2 \mathrm{~g} / \mathrm{kg}), \mathrm{Zn}(1.67 \mathrm{~g} / \mathrm{kg}), \mathrm{I}(0.042 \mathrm{~g} / \mathrm{kg}), \mathrm{Se}(0.017 \mathrm{~g} / \mathrm{kg})$, vitamin A $(280,000 \mathrm{IU} / \mathrm{kg}), \beta$-carotene $(2.27 \mathrm{~g} / \mathrm{kg})$, vitamin $\mathrm{D}_{3}(90,000 \mathrm{IU} / \mathrm{kg})$, and vitamin $\mathrm{E}(900 \mathrm{IU} / \mathrm{kg})$.

${ }^{6} \mathrm{DVE}=$ intestinal digestible protein (Tamminga et al., 1994).

${ }^{7} \mathrm{OEB}=$ degraded protein balance (Tamminga et al., 1994).

one sample per cow obtained between 3 and 1 d a.p. and sampling time $\mathrm{d}+1$ consisted of the first samples of each cow obtained postpartum (p.p.) that was obtained between 0 and 24 h p.p. Samples labeled as d +3 were obtained between d 2 and 4 p.p. To also study the effects of $\mathrm{P}$ deprivation relative to the onset of treatment, samples obtained on Friday morning of each week were expressed as samples of wk 0 to 4 , where wk 0 corresponded to the sampling time at the end of acclimation, and wk 1 to 4 to samples obtained at the end of the 1st to 4th wk of dietary P-deprivation. To limit the confounding effect of parturition on the analysis only weekly samples obtained a.p. were included, and samples obtained in the 4th wk of depletion (at time wk 4) were only included if obtained at least $7 \mathrm{~d}$ before calving.

Blood was collected in lithium heparin tubes and was kept at room temperature for up to $30 \mathrm{~min}$ until processed. Samples were centrifuged at $1,600 \times g$ for $15 \mathrm{~min}$ at $6^{\circ} \mathrm{C}$. Plasma was harvested and stored at $-20^{\circ} \mathrm{C}$ until analyzed. All samples were analyzed for plasma $[\mathrm{Pi}]$ (ammonium molybdate) and [Ca] (Arsenazo III) using an automatic analyzer (ABX Pentra 400, Horiba, Europe GmbH, Langenhagen, Germany). Plasma samples obtained at baseline, $\mathrm{d}-2, \mathrm{~d}+1$, and $\mathrm{d}+3$ from a subset of 5 randomly selected animals from each group were furthermore analyzed for concentrations of CrossLaps $([\mathbf{C T X}])$ as a marker for bone resorption, PTH, 25-hydroxyvitamin D ([25-OHD $]$, and 1,25-dihydroxyvitamin $\mathrm{D}\left(\left[\mathbf{1}, \mathbf{2 5}-(\mathbf{O H})_{2} \mathbf{D}\right]\right)$ as described below. Random selection of animals from the CON group for this analysis was conducted after prior exclusion of animals having received $\mathrm{Ca}$ salts either orally or parenterally. Weekly plasma samples of the 5 preselected cows per group were also analyzed for plasma $[\mathrm{CTX}]$ as described below to crudely determine 
the time pattern of the onset of bone resorption due to the treatment.

Analysis of CTX, PTH, and 25-OHD were conducted by means of commercially available ELISA [Serum CrossLaps ELISA, Immundiagnostic Systems (ids) GmbH, Frankfurt am Main, Germany; Bovine Intact PTH ELISA Kit; Immuntopics Inc., San Clement, CA; 25(OH)-Vitamin D direct day ELISA, Immundiagnostik AG, Bensheim, Germany]. Intra- and interassay coefficients in our laboratory and sensitivities were $9.76 \%$, $7.64 \%$, and $0.04 \mathrm{ng} / \mathrm{mL}$ for CrossLaps, $7.16 \%, 5.43 \%$, and $110 \mathrm{pg} / \mathrm{mL}$ for PTH, and $10.1 \%, 13.4 \%$, and 6.08 $\mathrm{ng} / \mathrm{mL}$ for $25-$ OHD. According to the manufacturer, cross-reactivity with other vitamin D metabolites compared with $25-\mathrm{OHD}_{3}$ is $67.8 \%$ for $25-\mathrm{OHD}_{2}$ and $100 \%$ for $24,25-(\mathrm{OH})_{2} \mathrm{D}_{3}$.

Measurement of plasma concentrations of $1,25-(\mathrm{OH})_{2} \mathrm{D}$ was carried out by a commercial diagnostic laboratory using a competitive ELISA following solvent extraction $\left[1,25-(\mathrm{OH})_{2}\right.$-Vitamin D ELISA, Immundiagnostik $\mathrm{AG}$. Intra- and interassay coefficients and sensitivities documented and provided by the laboratory are $6.69 \%, 9.00 \%$, and $4.80 \mathrm{pg} / \mathrm{mL}$. Cross-reactivity with $1,25-(\mathrm{OH})_{2} \mathrm{D}_{2}$ compared with $1,25-(\mathrm{OH})_{2} \mathrm{D}_{3}$ is declared to be $41 \%$.

Results are expressed as mean and standard deviation or as median and interquartile range for parameters that were not normally distributed. Normality of distribution was checked by Shapiro-Wilk's test for normality distribution and by checking probability plots. Log-transformations were used wherever appropriate to obtain normal distribution. Repeated measures ANOVA were conducted to determine effects of treatment, time, as well as treatment $\times$ time interactions using an autoregressive(1) model with cow identification as subject. Post hoc tests were used whenever $F$-test was significant. Bonferroni-corrected $P$-values were used and $P<0.05$ was considered statistically significant. All analyses were conducted with SAS software (SAS 9.3, SAS Institute Inc., Cary, NC).

All 18 cows completed the study and calved spontaneously or with mild to moderate assistance. Three of 9 cows of the CON group (2 cows entering fourth and 1 cow entering the fifth lactation) developed clinical signs of hypocalcemia early p.p. In all 3 cases treatments were administered after sample collection $\mathrm{d}+1$ and in 1 case after sample collection $d+3$. Treatment consisted of intravenous administration in 1 case and in 2 cases of subcutaneous administration of Ca salt solutions (10 $\mathrm{g}$ of $\mathrm{Ca}$ as $\mathrm{Ca}$ borogluconate). In all cases treatment was combined with repeated oral administration $\mathrm{Ca}$ salts. All treated cows recovered uneventfully within 72 $\mathrm{h}$ of treatment. Neither recumbency nor clinical signs of muscle weakness were noticed in the LP group.
The plasma $[\mathrm{Pi}]$ time curve relative to calving is presented in Figure 1. Plasma $[\mathrm{Pi}]$ showed a significant time, treatment, and time $\times$ treatment interaction effect $(P<0.001)$. Values of the LP group were significantly below baseline values and below the reference range for plasma [Pi] in cattle $(1.4-2.6 \mathrm{mmol} / \mathrm{L}$, Constable et al., 2016), during the entire study period and reached a nadir of $0.57 \pm 0.2 \mathrm{mmol} / \mathrm{L}$ at $\mathrm{d}+1$ (Figure 1). Differences between groups were significant at all sample times except baseline. In the CON group a numerical decline in plasma [Pi] was observed at $\mathrm{d}+1$ with a nadir of $1.04 \pm 0.4 \mathrm{mmol} / \mathrm{L}$. Differences over time however did not reach significance level in this group. Plasma [Ca] showed a significant time $(P<0.001)$ and treatment effect $(P=0.004)$ but no time $\times$ treatment interaction effect. In the CON group values measured at $d+1$ and +3 were significantly below concentrations measured at $d-2$ and -10 , values measured at $d+3$ were also significantly below values at $d+10$. A similar trend was observed in the LP group, but differences did not reach the significance level in this group (Figure 1). Group differences were identified at $\mathrm{d}+1$ and +3 , with values in the CON group on average being 0.19 and $0.26 \mathrm{mmol} / \mathrm{L}$ lower, respectively, than in the LP group (Figure 1). The median plasma [Ca] of the CON group but not of the LP group was below the reference for plasma $[\mathrm{Ca}]$ in cattle at the sampling times $\mathrm{d}+1$ and +3 (2.4-3.2 mmol/L, Constable et al., 2016).

Plasma $[\mathrm{PTH}]$ that was only analyzed at the baseline, $\mathrm{d}-2,+1$, and +3 times revealed a significant time $(P<0.001)$ and treatment effect $(P=0.026)$ but no time $\times$ treatment interaction effect (Table 2 ). Although differences over time were not significant in the LP group, a significant increase in plasma $[\mathrm{PTH}]$ at $\mathrm{d}+1$ and +3 compared with baseline as well as at $\mathrm{d}+1$ compared with $\mathrm{d}+3$ occurred in the CON group (Table 2). Significantly higher plasma $[\mathrm{PTH}]$ in the CON group compared with the LP group was measured at $\mathrm{d}+1$ and +3 . Plasma $[\mathrm{CTX}]$ showed a time effect $(P<0.001)$ and a weak treatment effect $(P=0.054$, Table 2). Values measured at $\mathrm{d}-2,+1$, and +3 in the LP group were higher than baseline values, and values measured at $\mathrm{d}+3$ were higher than values determined at $\mathrm{d}-2$ (Table 2). In the CON group values determined p.p. were higher than a.p. values. Differences between groups only reached the significance level at $d+3$ with higher concentrations in the LP group than the CON group (Table 2). Remarkably, plasma [CTX] showed a considerable degree of scatter that increased over time in the LP group, which was not observed in the CON group.

The concentrations 25 -OHD and 1,25- $(\mathrm{OH})_{2} \mathrm{D}$ determined in the present study are summarized in Table 2. No significant treatment, time, or treatment $\times$ time 
Table 2. Plasma concentrations (mean \pm SD or median and interquartile range in brackets) of CrossLaps (CTX), parathyroid hormone (PTH), 25-hydroxyvitamin $\mathrm{D}(25-\mathrm{OHD})$, and 1,25-dihydroxyvitamin $\mathrm{D}\left(1,25-\mathrm{OH}_{2} \mathrm{D}\right)$ at the baseline (end of acclimation), d -2 (between 3 and $1 \mathrm{~d}$ antepartum), $\mathrm{d}+1$ (within the first $24 \mathrm{~h}$ postpartum), and $\mathrm{d}+3$ (between 2 and $4 \mathrm{~d}$ postpartum) sampling times stratified by group (CON: control, LP: low P group) relative to parturition

Time of sampling

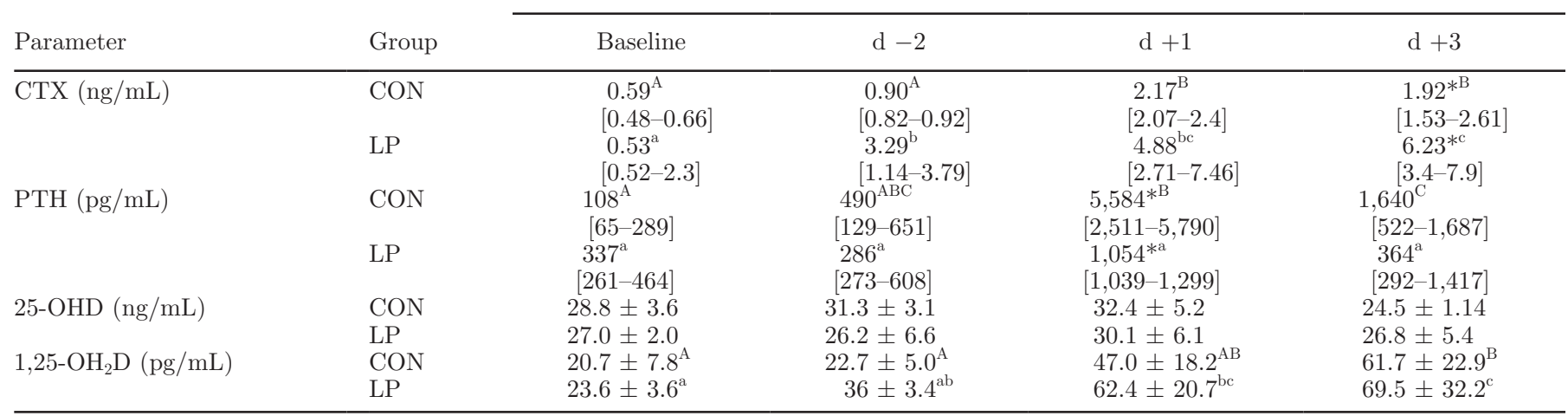

$\overline{{ }^{\mathrm{A}-\mathrm{C} ; \mathrm{a}-\mathrm{C}} \text { Values with different uppercase letters for the CON group and lowercase letters for the LP group within a row differ significantly between }}$ sampling times $(P<0.05$, Bonferroni corrected $)$.

*Values within the same column differ between groups $(P<0.05)$.

interaction effect was observed. For $1,25-(\mathrm{OH})_{2} \mathrm{D}$ a significant time effect $(P<0.001)$ but neither a treatment nor treatment $\times$ time interaction effect were identified. The mean $1,25-(\mathrm{OH})_{2} \mathrm{D}$ concentrations of both prepartum samples were significantly lower than at $d$ +3 in both groups. Values determined at $\mathrm{d}+1$ were significantly above baseline concentrations in the LP group (Table 2). Differences between groups were not observed at any sampling time point.

Plasma $[\mathrm{Ca}],[\mathrm{Pi}]$, and $[\mathrm{CTX}]$ relative to the duration of dietary $\mathrm{P}$ deprivation are presented in Table
3. Plasma $[\mathrm{Pi}]$ showed a significant treatment $(P=$ $0.008)$, time $(P=0.033)$, and time $\times$ treatment interaction effect $(P=0.048)$. Whereas in the CON group no change in plasma $[\mathrm{Pi}]$ was observed between wk 0 and 4, a numerical decline became noticeable within 1 wk of dietary P-deprivation. Differences to baseline values, however, were only significant at wk 2 and 4 (Table 3). Significant treatment, time, and treatment $\times$ time interaction effects $(P<0.001)$ were identified for plasma $[\mathrm{Ca}]$. The plasma $[\mathrm{Ca}]$ of the LP group was significantly higher than baseline (wk 0) values from
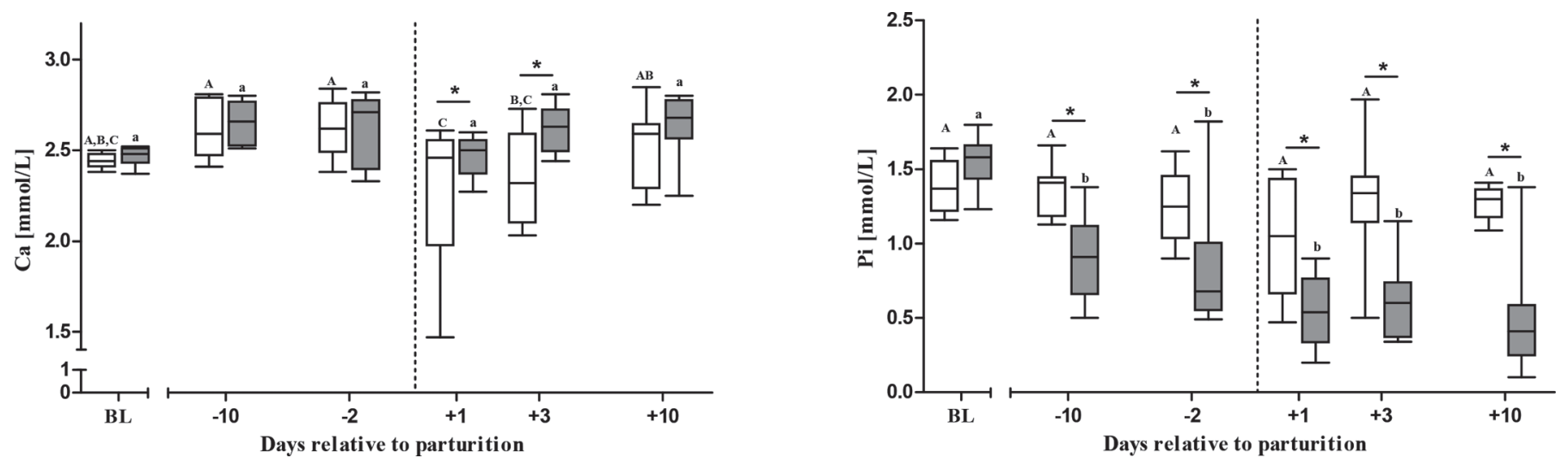

Figure 1. Plasma concentrations of total Ca (left panel) and inorganic P (Pi, right panel) of cows of the control (CON) group (open boxes) and cows of the low P (LP) group (gray boxes) at the sampling times baseline (BL, end of acclimation), d -10 (between 11 and $9 \mathrm{~d}$ antepartum), $\mathrm{d}-2$ (between 3 and $1 \mathrm{~d}$ antepartum), $\mathrm{d}+1$ (within the first $24 \mathrm{~h}$ postpartum), and $\mathrm{d}+3$ (between 2 and $4 \mathrm{~d}$ postpartum). Box and whisker plots represent median (horizontal line), lower and upper quartiles (bottom and top of box, respectively), as well as the range (lower and upper end of whiskers, respectively). The vertical dashed line represents time of parturition. Values labeled with different uppercase (group CON) and lowercase (group LP) letters differ significantly within the same group $(P<0.05$, Bonferroni corrected); values labeled with * differ significantly between groups at the same sampling time $(P<0.05)$. 
Table 3. Plasma concentrations (as mean $\pm \mathrm{SD}$, or median and interquartile range in brackets) of total Ca, inorganic $\mathrm{P}$ (Pi), and CrossLaps (CTX; Immundiagnostic Systems GmbH, Frankfurt am Main, Germany) at the sampling times wk 0 (end of acclimation), and wk 1 to 4 (corresponding to number of weeks of dietary P deprivation antepartum) stratified by group (CON: control, LP: low P group)

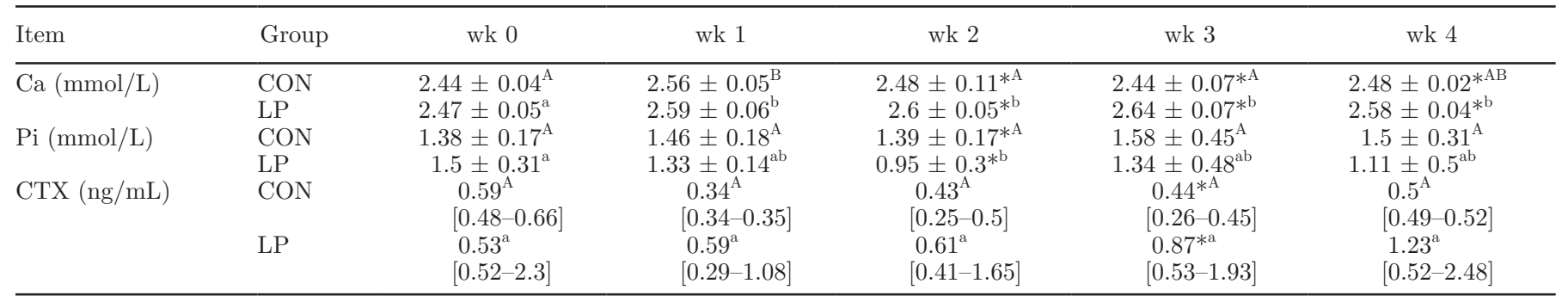

$\overline{\mathrm{A}, \mathrm{B} ; \mathrm{a}-\mathrm{C}}$ Values with different uppercase letters for the CON group and lowercase letters for the LP group within a row differ significantly between sampling times $(P<0.05$, Bonferroni corrected).

*Values within the same column differ between groups $(P<0.05)$.

wk 1 to 3 (Table 3). In the CON group, significantly elevated plasma $[\mathrm{Ca}]$ relative to baseline was only observed at wk 1. The plasma [Ca] of the LP group was significantly higher than in the CON group from wk 2 to 4 (Table 3). Plasma [CTX] when expressed relative to onset of dietary $\mathrm{P}$ deprivation revealed a significant treatment effect $(P=0.0091)$ but no time or treatment $\times$ time interaction effects. As was mentioned with [CTX] when expressed relative to calving, plasma [CTX] showed a considerably larger degree of scatter in the LP group, which tended to increase over time resulting in an increase of the 3rd interquartile, whereas the 1st interquartile remained unchanged over time. Significant differences between groups only were determined at wk 3 .

The results presented here show a positive effect of dietary $\mathrm{P}$ deprivation in late gestation on plasma $[\mathrm{Ca}]$ of periparturient cows with a lower incidence of clinical hypocalcemia and with plasma $[\mathrm{Ca}]$ in $\mathrm{P}$ depleted cows in the range of 10 to $15 \%$ above the values of control cows in the first $3 \mathrm{~d}$ of lactation. This is in line with earlier studies on low $\mathrm{P}$ intake a.p. in which plasma $[\mathrm{Ca}]$ p.p. was increased (Barton et al., 1987), the incidence of clinical periparturient paresis was decreased (Kichura et al., 1982) or the transient decline in plasma [Ca] at parturition was less pronounced (Peterson et al., 2005). Phosphorus deprivation in this study was associated with marked treatment effects on plasma [PTH] during the periparturient period. Lower secretion of PTH in states of $\mathrm{P}$ deficiency is well documented in cattle and other species and is thought to either be a consequence of increased plasma [Ca] in P-deficient animals mobilizing bone or enhanced activation of $25-\mathrm{OHD}_{3}$ to $1,25-\mathrm{OH}_{2} \mathrm{D}_{3}$ occurring in states of P-deprivation (Bergwitz and Jüppner, 2011; Anderson et al., 2017). Enhanced PTH secretion in response to declining plasma [Ca] around calving is considered the key regulatory mechanism to control periparturient hypocalcemia through activation of bone resorption. Lower plasma $[\mathrm{PTH}]$ in P-deprived cows in this study suggests that a regulatory circuit independent of PTH but equally effective in mobilizing bone tissue is triggered by dietary $\mathrm{P}$ deprivation. Although enhanced bone mobilization in states of $\mathrm{P}$ deficiency is well accepted, the physiological relevance of this phenomenon has been questioned in the past (Thompson et al., 1975; Ivey et al., 1978; Kichura et al., 1982). Higher plasma [CTX] and increased plasma [Ca] in P-depleted compared with control animals observed in this study suggest that bone turnover was triggered to a physiologically relevant degree as can be concluded from the differences in plasma $[\mathrm{Ca}]$ and in incidence rates of clinical hypocalcemia in periparturient cows between groups. Similar effects were reported to occur in nonperiparturient lactating cattle and in pigs (Liesegang et al., 2002; Grünberg et al., 2015).

Interestingly, the marked difference in plasma $[\mathrm{PTH}]$ between groups was not associated with remarkable differences in the plasma concentrations of $1,25-\mathrm{OH}_{2} \mathrm{D}$ between groups. This result is in good agreement with the findings of a recent study conducted in beef cattle (Anderson et al., 2017) and points to a potential role of fibroblast growth factor 23 (FGF23), a bone-derived phosphatonin that was characterized for the first time in 2000 (Schiavi and Kumar, 2004). Low dietary P intake was demonstrated to decrease plasma concentrations of FGF23 and concomitantly increase $1,25-\mathrm{OH}_{2} \mathrm{D}_{3}$ in humans while plasma [PTH] was low (Antoniucci et al., 2006). In the current study no differences in plasma concentrations of $1,25-(\mathrm{OH})_{2} \mathrm{D}$ between groups were observed either before or around parturition. Synthesis of $1,25-(\mathrm{OH})_{2} \mathrm{D}$ by the enzyme 1 - $\alpha$-hydroxylase is regulated by the interplay of several factors including plasma Ca, FGF23, and PTH. We speculate that the decrease in plasma $[\mathrm{Pi}]$ a.p. may have triggered a decrease of the plasma FGF23 concentration as this was reported for mice (Perwad et al., 2005). The ensuing stimula- 
tion of the 1- $\alpha$-hydroxylase (Shimada et al., 2004) may have been counterbalanced by the inhibitory effect of the concomitantly elevated plasma $[\mathrm{Ca}]$ resulting from bone mobilization until parturition (Bushinsky et al., 1985). At the onset of lactation, the assumed decline of plasma FGF23 concentrations in P-depleted cows may then have altered the tissue responsiveness to $\mathrm{PTH}$ and decreasing $[\mathrm{Ca}]$, which could explain the timely increase in $1,25-(\mathrm{OH})_{2} \mathrm{D}$ despite the lower PTH peak at parturition in P-depleted animals.

The present study is based on a small sample size and furthermore included one-third of animals of the control group that underwent medically indicated treatment with Ca salts, thereby likely biasing the results and the power of the statistical analysis presented here. Although results of $d+1$ were obtained before treatment and thus were unaffected by Ca treatment, it is probable that the difference in plasma [Ca] between groups at $\mathrm{d}+3$ would have been more pronounced, if these cows of the CON group had not been supplemented with Ca. Another finding of this study that is likely an artifact of sample selection is the difference in variation in plasma [CTX] between groups. Whereas in the LP group random selection of samples for CTX analysis included all animals of the group, the 3 cows with clinical hypocalcemia having received treatment were not considered for random selection in the CON group to avoid confounding effects of treatment. This approach, however, created a selection bias skewing the age distribution in the CON group toward younger animals, which probably contributed to the lower degree of scatter observed in this group.

In conclusion, although many strategies for prevention of periparturient hypocalcemia are based on the concept of stimulating PTH secretion and activating vitamin $\mathrm{D}$, the results of this study suggest that other, yet undetermined mechanisms that are not dependent on or are less dependent on PTH secretion, but are equally effective in sustaining the plasma [Ca] of the periparturient cow, must be considered. Future studies should aim at identifying these mechanisms and exploring the degree and duration of dietary P-deprivation required during late gestation to trigger a degree of bone mobilization effective in sustaining periparturient plasma [Ca]. Furthermore, studies investigating deleterious effects of dietary P-deprivation in late gestation on health and productivity during the following lactation are warranted.

\section{ACKNOWLEDGMENTS}

This study was partially funded by ZuivelNL (Zoetermeer, the Netherlands), the organization of the Dutch dairy supply. The authors furthermore acknowledge the assistance of Paul Dobbelaar with formulating the experimental rations, as well as the support from the H. Wilhelm Schaumann Stiftung (Hamburg, Germany).

\section{REFERENCES}

Anderson, S. T., L. J. Kidd, M. A. Benvenutti, M. T. Fletcher, and R. M. Dixon. 2017. New candidate markers of phosphorus status in beef breeder cows. Anim. Prod. Sci. 57:2291-2303. https://doi .org/10.1071/AN17363.

Antoniucci, D. M., T. Yamashita, and A. A. Portale. 2006. Dietary phosphorus regulates serum fibroblast growth factor-23 concentrations in healthy men. J. Clin. Endocrinol. Metab. 91:3144-3149. https://doi.org/10.1210/jc.2006-0021.

Barton, B. A., N. A. Jorgensen, and H. F. DeLuca. 1987. Impact of prepartum dietary phosphorus intake on calcium homeostasis at parturition. J. Dairy Sci. 70:1186-1191. https://doi.org/10.3168/ jds.S0022-0302(87)80130-3.

Bergwitz, C., and H. Jüppner. 2010. Regulation of phosphate homeostasis by PTH, vitamin D, and FGF23. Annu. Rev. Med. 61:91104. https://doi.org/10.1146/annurev.med.051308.111339.

Bergwitz, C., and H. Jüppner. 2011. Phosphate sensing. Adv. Chronic Kidney Dis. 18:132-144. https://doi.org/10.1053/j.ackd.2011.01 .004 .

Bushinsky, D. A., G. S. Riera, M. J. Favus, and F. L. Coe. 1985. Evidence that blood ionized calcium can regulate serum $1,25(\mathrm{OH})_{2} \mathrm{D}_{3}$ independently of parathyroid hormone and phosphorus in the rat. J. Clin. Invest. 76:1599-1604. https://doi.org/10.1172/JCI112143.

Constable, P. D., K. W. Hinchcliff, S. H. Done, and W. Grünberg. 2016. Veterinary Medicine-E-Book: A Textbook of the Diseases of Cattle, Horses, Sheep, Pigs and Goats. Elsevier Health Sciences, Amsterdam, the Netherlands.

Curtis, C. R., H. N. Erb, C. J. Sniffen, R. D. Smith, P. A. Powers, M. C. Smith, M. E. White, R. B. Hillman, and E. J. Pearson. 1983. Association of parturient hypocalcemia with eight periparturient disorders in Holstein cows. J. Am. Vet. Med. Assoc. 183:559-561.

Goff, J. P. 2018. Invited review: Mineral absorption mechanisms, mineral interactions that affect acid-base and antioxidant status, and diet considerations to improve mineral status. J. Dairy Sci. https://doi.org/10.3168/jds.2017-13112.

Grünberg, W. 2014. Treatment of phosphorus balance disorders. Vet. Clin. North Am. Food Anim. Pract. 30:383-408. https://doi.org/ 10.1016/j.cvfa.2014.03.002.

Grünberg, W., P. Scherpenisse, P. Dobbelaar, M. J. Idink, and I. D. Wijnberg. 2015. The effect of transient, moderate dietary phosphorus deprivation on phosphorus metabolism, muscle content of different phosphorus-containing compounds, and muscle function in dairy cows. J. Dairy Sci. 98:5385-5400. https://doi.org/10.3168/ jds.2015-9357.

Ivey, J. L., E. R. Morey, and D. J. Baylink. 1978. The effects of phosphate depletion on bone. Adv. Exp. Med. Biol. 103:373-380.

Kichura, T. S., R. L. Horst, D. C. Beitz, and E. T. Littledike. 1982. Relationships between prepartal dietary calcium and phosphorus, vitamin D metabolism, and parturient paresis in dairy cows. J. Nutr. 112:480-487.

Lean, I. J., P. J. DeGaris, D. M. McNeil, and E. Block. 2006. Hypocalcemia in dairy cows: Meta-analysis and dietary cation anion difference theory revisited. J. Dairy Sci. 89:669-684. https://doi .org/10.3168/jds.S0022-0302(06)72130-0.

Liesegang, A., R. Ursprung, J. Gasser, M. L. Sassi, J. Risteli, J. L. Riond, and M. Wanner. 2002. Influence of dietary phosphorus deficiency with or without addition of fumaric acid to a diet in pigs on bone parameters. J. Anim. Physiol. Anim. Nutr. (Berl.) 86:1-16. https://doi.org/10.1046/j.1439-0396.2002.00355.x.

Martinez, N., L. D. Sinedino, R. S. Bisinotto, E. S. Ribeiro, G. C. Gomes, F. S. Lima, L. F. Greco, C. A. Risco, K. N. Galvao, D. Taylor-Rodriguez, J. P. Driver, W. W. Thatcher, and J. E. Santos. 
2014. Effect of induced subclinical hypocalcemia on physiological responses and neutrophil function in dairy cows. J. Dairy Sci. 97:874-887. https://doi.org/10.3168/jds.2013-7408.

NRC. 2001. Nutrient Requirements of Dairy Cattle. 7th rev. ed. Natl. Acad. Press, Washington, DC.

Oetzel, G. R. 2013. Oral calcium supplementation in peripartum dairy cows. Vet. Clin. North Am. Food Anim. Pract. 29:447-455. https://doi.org/10.1016/j.cvfa.2013.03.006.

Perwad, F., N. Azam, M. Y. Zhang, T. Yamashita, H. S. Tenenhouse, and A. A. Portale. 2005. Dietary and serum phosphorus regulate fibroblast growth factor 23 expression and 1,25-dihydroxyvitamin D metabolism in mice. Endocrinology 146:5358-5364. https://doi .org/10.1210/en.2005-0777.

Peterson, A. B., M. W. Orth, J. P. Goff, and D. K. Beede. 2005. Periparturient responses of multiparous Holstein cows fed different dietary phosphorus concentrations prepartum. J. Dairy Sci. 88:35823594. https://doi.org/10.3168/jds.S0022-0302(05)73043-5.

Reinhardt, T. A., J. D. Lippolis, B. J. McCluskey, J. P. Goff, and R. L. Horst. 2011. Prevalence of subclinical hypocalcemia in dairy herds. Vet. J. 188:122-124. https://doi.org/10.1016/j.tvjl.2010.03.025.
Rodriguez, E. M., A. Aris, and A. Bach. 2017. Associations between subclinical hypocalcemia and postparturient diseases in dairy cows. J. Dairy Sci. 100:7427-7434. https://doi.org/10.3168/jds .2016-12210

Schiavi, S. C., and R. Kumar. 2004. The phosphatonin pathway: New insights in phosphate homeostasis. Kidney Int. 65:1-14. https:// doi.org/10.1111/j.1523-1755.2004.00355.x.

Shimada, T., M. Kakitani, Y. Yamazaki, H. Hasegawa, Y. Takeuchi, T. Fujita, S. Fukumoto, K. Tomizuka, and T. Yamashita. 2004 Targeted ablation of Fgf23 demonstrates an essential physiological role of FGF23 in phosphate and vitamin D metabolism. J. Clin. Invest. 113:561-568. https://doi.org/10.1172/JCI19081.

Tamminga, S., W. M. Vanstraalen, A. P. J. Subnel, R. G. M. Meijer, A. Steg, C. J. G. Wever, and M. C. Blok. 1994. The Dutch protein evaluation system-The DVE/OEB-system. Livest. Prod. Sci 40:139-155. https://doi.org/10.1016/0301-6226(94)90043-4.

Thompson, E. R., D. J. Baylink, and J. E. Wergedal. 1975. Increases in number and size of osteoclasts in response to calcium or phosphorus deficiency in the rat. Endocrinology 97:283-289. https:// doi.org/10.1210/endo-97-2-283. 